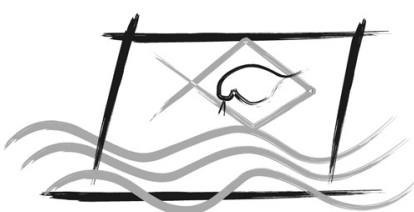

ECOTOX - BRASIL

\title{
Genotoxicity of Selected Pesticides in the Hen's Egg Test for Micronucleus Induction
}

\author{
M. Basilio da Conceição* \& B. Lovizutto Protti \\ ${ }^{1}$ Laboratório de Genética Molecular, CTTMar, \\ Universidade do Vale do Itajaí, Itajaí, SC, Brasil.
}

(Received November 10, 2009; Accept July 11, 2011)

\begin{abstract}
The presence of toxic substances in natural environments can potentially cause several alterations in organisms. Therefore, it becomes important the use of tests in order to evaluate the potential genotoxicity of these substances. In this work it was used the frequency of micronuclei in hen's embryos as toxic end point for evaluation of the genotoxic effect of the substances tested. Fertilized eggs of Gallus gallus domesticus were collected and incubated during eleven days. In the eighth day of incubation, the agrochemicals quinclorac, fipronil and pyrazosulfuron-ethyl, used in the irrigated rice culture, were injected and in the eleventh day, a sample of blood was taken. The analysis included the calculation of the frequency of micronuclei for 1000 polychromatic erythrocytes (PCE), to measure genotoxic damages. To evaluate the cytotoxic damages, the ratio between polychromatic erythrocytes and normochromatic erythrocytes was calculated (PCE/NCE). Results demonstrated that the technique is simple, sensible and of easy application. For the dose of $2.7 \mathrm{mg} / \mathrm{kg}$ the insecticide fipronil showed significant effect for the presence of micronucleus as well as in the dose of $104.2 \mathrm{mg} / \mathrm{kg}$ for the pyrazosulfuron-ethyl herbicide. The herbicide quinclorac did not show significant effects in none of the tested doses. We therefore conclude that these agrochemicals should be better studied with regard to its damaging potential to the environment and to human beings.
\end{abstract}

Key words: Pesticides, genotoxicity, micronucleus, hen's embryos.

\section{Genotoxicidade de alguns pesticidas no teste com ovos de galinha através da indução de micronúcleos}

\section{Resumo}

A presença de substâncias tóxicas pode, potencialmente, causar inúmeras alterações nos organismos presentes no ambiente natural, pelo que se faz necessário à utilização de testes que consigam avaliar o potencial genotóxico destas substâncias. Neste trabalho empregou-se a freqüência de micronúcleos em embriões de Gallus gallus domesticus, como parâmetro toxicológico para avaliação do efeito de substâncias genotóxicas. Os ovos fertilizados de Gallus gallus domesticus foram coletados e incubados durante onze dias. No oitavo dia de incubação, os agroquímicos quinclorac, fipronil e pyrazosulfuron-etil, utilizados na cultura de arroz irrigado, foram injetados e no décimo primeiro dia, foi retirada uma amostra de sangue. A análise incluiu o cálculo da freqüência de micronúcleos por 1000 células em eritrócitos policromáticos (PCE), para analisar os danos genotóxicos. Para avaliar os danos citotóxicos foi calculada a razão entre eritrócitos policromáticos e eritrócitos normocromáticos (PCE/NCE). Os resultados obtidos demonstraram que a técnica é simples, sensível e de fácil aplicação. A dose $2,7 \mathrm{mg} / \mathrm{kg}$ do inseticida fipronil mostrou efeito significativo para a presença de micronúcleo assim como na dose de 104,2 mg/kg do herbicida pyrazosulfuron-etil. O herbicida quinclorac não mostrou efeitos significativos em nenhuma das doses testadas. Conclui-se que estes agroquímicos devem ser mais bem estudados com relação a seu potencial de dano para o ambiente e para o ser humano.

Palavras-chave: Pesticidas, genotoxicidade, micronúcleos, embriões de galinha. 


\section{INTRODUCTION}

Pesticides have a worldwide application in agriculture and after the Second World War they have been used in increasing amounts each year, to cope with the needs of a growing world population. These agrochemicals have become inevitable in intensive agriculture to improve production and protect stored crops. Although pesticide use benefits the human population, health risks have been suggested in people occupationally exposed to these agrochemicals. Among the long-term health effects considered, the risk of cancer has been one of the more intensively studied. Toxic effects of pesticides over the ecosystem should also be known and diminished, because the extensive environmental distribution of these xenobióticos (Grover \& Kaur, 1999; Sanches et al., 2003).

Rice culture (Oryza sativa) is one of the main grain production activities in Santa Catarina State, and is the most economically important crop in Itajaí-Açú River Valley. Cultured areas are restricted to the fertile flat valleys, which can be easily flooded and drained according the needs of this crop. The culture of the irrigated rice in the south of Brazil is characterized by the intense use of many pesticides, mainly herbicides, insecticides, and the sporadically use of fungicides. In most cultured places, flooding follows the pesticide application or as well as in the pre-emerged system, the chemicals are directly applied over the water film. Depending on farmers water management use and raining conditions after the application the pesticides, there is a risk of the chemicals residues been carried out of the culture and contaminate the water resources of this region (Resgalla et al., 2002).

Some pesticides used in rice culture in this area include the insecticide Fipronil, which is registered for use to control pests of corn, cotton and rice in several parts of the world. The mode of action involves blocking the $\gamma$-aminobutyric acid (GABA)gated chloride channel with much greater sensitivity of this target in insects than in mammals (Hainzl \& Casida, 1996).

Pyrazosulfuron-ethyl is a new rice herbicide that is a sulfonylurea group pesticide. It has eminent activity against a broad spectrum of annual and perennial rice paddy weeds, especially broad leaf weeds and sedges, with pre-emergence and early post-emergence application and at extremely low use rates. Pyrazosulfuron-ethyl has acute oral (rat) LD50 value more than $5,000 \mathrm{mg} / \mathrm{kg}$ and acute dermal (rat) LD50 value more than $2,000 \mathrm{mg} / \mathrm{kg}$ indicating that this herbicide is safe to livestock and human beings (Rodrigues \& Almeida, 1998).

Quinclorac is another pesticide used in rice culture and belongs to a new class of highly selective auxin herbicides. Quinclorac is used in rice to control dicotyledonous and monocotyledonous weeds, particularly barnyardgrass (Echinochloa crus-galli). Quinclorac has also been developed for use in turfgrass areas, spring wheat and chemical fallow. Quinclorac is readily absorbed by germinating seeds, roots, and leaves and is translocated acropetally and basipetally. Quinclorac mimics an auxin overdose, stimulating the induction of 1-aminocyclopropane-1-carboxylic acid (ACC) synthase activity, which promotes ethylene biosynthesis. This herbicide is only slightly toxic for many aquatic species tested (Rodrigues \& Almeida, 1998).

A large number of biomarkers are available to assess transient and permanent genotoxic responses of exposure to pesticides. In present study, selected pesticides of different chemical classes were tested for genotoxicity in the hen's egg test for micronucleus induction (HET-MN). The micronucleus test is one of the in vivo assays more widely used to evaluate DNA damage caused by clastogenic and aneugenic substances and plays a important role in genetic toxicology in evaluating the genotoxic potential of xenobiotics. This assay was first developed for mice bone marrow erythrocytes but was further used in rats and many others animal species (Ribeiro et al., 2003; Dias et al., 2005).

Chick embryos have complex metabolic competence; therefore they serve as good model system for genotoxic testing, and are capable of covering metabolic activation and deactivation of xenobiotics. Wolf and Luepke (1997) described the formation of micronuclei in the erythrocytes of peripheral blood of incubated hen's eggs as a measure of genotoxicity, and demonstrated a positive response after administration of direct acting mutagens and promutagens. The protocol was further improved with additional important methodological aspects including an optimal time frame, a new proliferation marker, and the better rout of administration of the drugs. The hen's egg test for micronucleus induction was considered to be extremely simple, inexpensive and rapid, and as combining the use of commonly accepted genetic endpoint (formation of micronuclei) with the well characterized model of the chick embryo (Wolf et al., 2002).

In this work we examined the potential to induce micronuclei in hen's eggs erythrocytes of the insecticide Fipronil and the herbicides Quinclorac and Pyrazosulfuronethyl commonly used in the rice culture.

\section{MATERIAL AND METHODS}

\section{Incubation}

Fertilized eggs were obtained from a commercial hatchery (white leghorn, Avícola Polastri, LTDA, Itajai, SC, Brazil). The eggs were incubated horizontally in an automatically rotating ( $3 \mathrm{~h}$ intervals) incubator at $37.5{ }^{\circ} \mathrm{C}$ and a relative humidity of $63 \%$. It was considered as day 1 an incubation period of 24 hours. All tested substances were administered on day 8 of incubation and blood was sampled $72 \mathrm{~h}$ later on day 11 .

\section{Test substances}

All the agrochemicals tested were obtained from the EPAGRI (Empresa de Pesquisa Agropecuária e Extensão Rural de Santa Catarina, Estação Experimental de Itajaí). The pesticides used were the insecticide Fipronil (CAS No. 
120068-37-3), and the herbicides Quinclorac (CAS No. 84087-01-4) and Pyrazosulfuron-ethyl (CAS No. 93697-746). A control group (distillated water) was also run. Methyl methanesulfonate, a well-known genotoxic molecule was employed as a positive control. Since no data for toxic dosages were available to these pesticides for Gallus gallus domesticus, we made a previous experiment to choose the test doses to be used in this assay taking into account data for others species like fishes and rats (Resgalla et al., 2002).

\section{Drug administration}

For administration four eggs for each dose were used, and on day 8 the egg shell was opened to obtain access to the air cell, where all the test substances were pipetted directly onto the inner shell membrane. All substances were diluted in distillated water to a final volume of $100 \mu$ l. The hole was covered by a piece of adhesive tape to ensure the embryo's health until blood sampling takes place. Tested doses are showed in Table 1.

\section{Blood sampling and staining of smears}

After $72 \mathrm{~h}$ of exposure to pesticides, $20 \mu \mathrm{l}$ of blood was sampled from embryos and immediately mixed with 20 $\mu 1$ of a $0.5 \%$ methylene blue solution and $0.5 \mathrm{ml}$ of this mixture was spread out on slides. The blood smear was air dried and fixed with methanol for $10 \mathrm{~min}$. Subsequently, the slides were stained with $0.007 \%$ acridine orange solution (Suginara et al., 2000).

\section{Scoring of micronuclei}

All slides were coded for analysis. The examination was performed using an Olympus BX40 microscope under reflected light fluorescence and photographed using a digital camera (Nikon, Coolpix 5000). The main criterion for scoring a structure as micronucleus were its general similarity to the

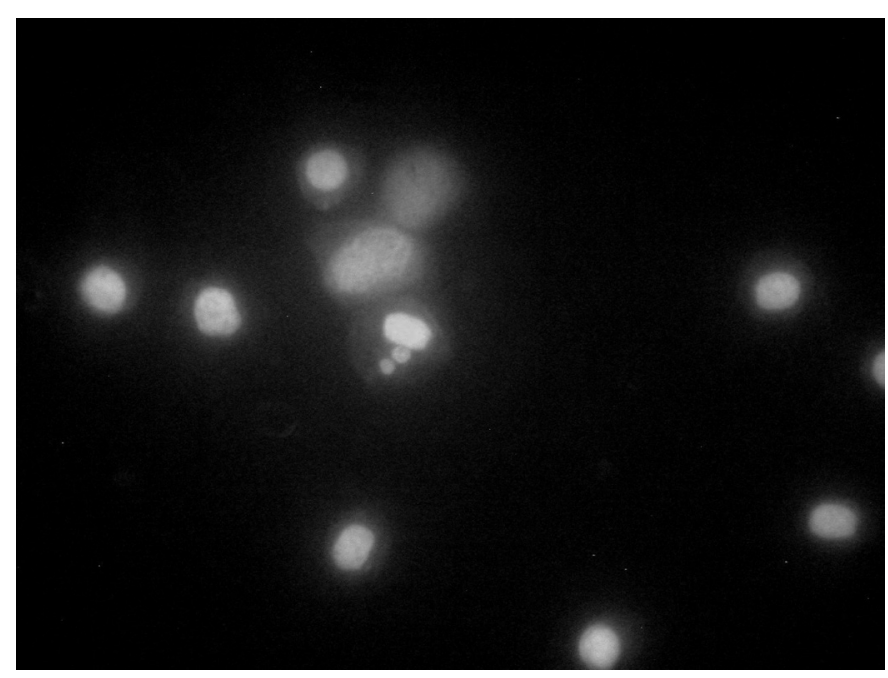

Figure 1 - Micronucleus in polychromatic erythrocyte (PCE) of Gallus gallus domesticus $(1,000 \mathrm{x})$ cell nucleus, the maximum size not exceeding two thirds of the size of nucleus, it has to show a distinct border and should be round to oval shaped (Figure 1).

The possible effects of pesticides exposure was detected by the frequency of micronucleus in at least 1,000 polychromatic erythrocytes (PCE), and the ratio PCE/NCE (normochromatic erythrocytes) was determined by counting a total of 1,000 erythrocytes, and served as proliferation marker. The micronuclei means among treatments were statistically compared using an ANOVA - LSD test. Significance level was fixed in $5 \%$.

\section{RESULTS}

The frequency of micronuclei in erythrocytes of hen's (Gallus gallus domesticus) embryos has proven to be sensitive in depicting the exposure effects to the assayed pesticides in this study. The test also seems to be technically simple and inexpensive when compared to others usually employed in environmental toxicology as suggested by Wolf et al. (2002).

The results of the pesticides tested in present study are provided in Table 1. The analysis of the mean number of micronucleus per 1,000 cells showed significant results for the insecticide Fipronil at a dose of $2.7 \mathrm{mg} / \mathrm{kg}$, and for the herbicide Pyrazosulfuron-ethyl at a dose of $104.2 \mathrm{mg} /$ $\mathrm{kg}$, inducing micronucleus at higher rates than the negative control. The herbicide Quinclorac induced micronuclei at lower rates and was not statistically different from the control group $(\mathrm{p}>0.05)$ at the doses tested in this study (Table 1$)$. The results also showed an increase of the ratio PCE/NCE for the pesticide treated individuals when compared with the control group.

\section{DISCUSSION}

Fipronil is considered an excellent insecticide because of its good selectivity between insects and mammals. The insecticide action involves blocking the $\gamma$-aminobutyric acid-gated chloride channel with greater sensitivity of this target in insects than in mammals. Nevertheless, Hainzl and Casida (1996) showed that Fipronil have photoproducts like desulfinylfipronil that have higher neurotoxicity to insects and also for mammals, suggesting that safety evaluations should take in to account not only the parent compound but also its photoproducts found in the environment. In the rice culture usually Fipronil is used in the seeds at a dose of $0.16 \mathrm{~g}$ for each $100 \mathrm{~kg}$ of seeds (SOSBAI, 1993), and is considered as a WHO Class II moderately hazardous pesticide, with a rat acute oral LD50 of $97 \mathrm{mg} / \mathrm{kg}$ (WHO, 1999). Fipronil is carcinogenic to rats at doses of $300 \mathrm{ppm}$ in males and females $(12.68 \mathrm{mg} / \mathrm{kg} /$ day for males and $16.75 \mathrm{mg} / \mathrm{kg} /$ day for females) (USEPA, 1996), causing thyroid cancer related to disruption in the thyroid-pituitary status (Hurley et al., 1998). In this study Fipronil showed significant genotoxic effects at a dose of $2.7 \mathrm{mg} / \mathrm{kg}$ in eggs of birds. Therefore, we suggest that more 
Table 1 - Micronuclei in hen's embryos polychromatic erythrocytes and PCE/NCE ratio. PCE: polychromatic erythrocytes. NCE: normochromatic erythrocytes. MMS: methyl methanesulfonate.

\begin{tabular}{lccc}
\hline Pesticides & Dose/egg & MN-PCE/1000cells & PCE/NCE ratio \\
& $(\mathbf{m g} / \mathbf{k g})$ & (mean, \pm SD) & (mean, \pm SD) \\
\hline Control $\left(\mathrm{H}_{2} \mathrm{O}\right)$ & 0.00 & 0.00 & $1.24 \pm 0.45$ \\
MMS $^{\text {a }}$ & 7.3 & $4.5 \pm 1.7^{*}$ & $11.31 \pm 11.6$ \\
fipronil & 1.74 & $1.25 \pm 1.2$ & $7.15 \pm 4.9$ \\
fipronil & 2.43 & $1.0 \pm 1.4$ & $7.42 \pm 2.73$ \\
fipronil & 2.7 & $1.5 \pm 1.0^{*}$ & $4.86 \pm 2.3$ \\
pyrazosulfuron-ethyl & 1.6 & $0.25 \pm 0.50$ & $13.88 \pm 2.3$ \\
pyrazosulfuron-ethyl & 104.2 & $1.5 \pm 1.7^{*}$ & $10.81 \pm 11.8$ \\
pyrazosulfuron-ethyl & 116.0 & $0.75 \pm 0.50$ & $9.27 \pm 8.9$ \\
quinclorac & 16.6 & $0.25 \pm 0.50$ & $9.55 \pm 5.8$ \\
quinclorac & 23.3 & $0.25 \pm 0.50$ & $5.99 \pm 1.7$ \\
quinclorac & 30.0 & $0.5 \pm 0.58$ & $5.34 \pm 3.1$ \\
\hline
\end{tabular}

aPositive control.

$* \mathrm{p}<0,05$

studies have to be done to best evaluate its effect over aquatic environments, since it is considered high toxic to some fish and aquatic invertebrates (USEPA, 1996; Diallo et al., 1998).

Toxicity experiments are routinely performed to determine the risk of substances for test organisms through time. However, the bioavailability of toxic concentrations and forms of a substance may not be accurately assessed when an organism remains in the test chamber for long periods of exposure. This may explain why some times only few tested doses shows significant effects in a test. However, in this study we can not say that since the tested substances were direct injected into the individuals. The herbicides Quiclorac and Pyrazosulfuron-ethyl are considered by the WHO (2004) as non-toxic under normal handling practices, however in this study we could see that only the herbicide Pyrazosulforonethyl did induce micronuclei formation in the embryos at the tested dose of $104,2 \mathrm{mg} / \mathrm{kg}$, however it failed to show significant effect at $116.0 \mathrm{mg} / \mathrm{kg}$. This may have occurred due to the small difference between the concentrations used. Nonlinear dose response assessment has its origins in the threshold hypothesis, which holds that a range of exposures from zero to some finite value can be tolerated by the organism with essentially no chance of expression of the toxic effect, and the threshold of toxicity is where the effects (or their precursors) begin to occur. Therefore, we suggest that both concentrations should be close to this threshold. The recommended dosage for this chemical is about $150-300 \mathrm{~g} / \mathrm{ha}$ in rice cultured areas, and since it induced MNs at a dose of $104.2 \mathrm{mg} / \mathrm{kg}$ (Table 1) is advisable to implement environmental studies to analyze the presence of this herbicide in the aquatic environments close to the rice cultured fields in the studied area, and after that evaluation of the genotoxic potential of these chemicals over the organisms inhabiting these ecosystems.

The micronucleus assay always requires a proof of proliferation, since the formation of micronucleus depends upon mitosis. An anti-proliferative effect of the test substance is prone to produce a false negative result as a consequence of a suppressed cell division (Wolf \& Luepke, 1997). In this study it was observed that all tested chemicals produced an increase in the PCE/NCE ratio, probably indicating a recuperation phase after a small cytotoxic attack, therefore enough immature cell were present during most of the experiment time, meaning that when micronucleus were not detected this results should not be considered a false negative.

In conclusion, ours results confirms the genotoxic potential of the insecticide Fipronil and the herbicide Pyrazosulfuronethyl to induce micronuclei in embryos of Gallus gallus domesticus, and also the potential of this test as biomarkers for environmental xenobiotics.

\section{REFERENCES}

DIALLO, A.O.; DIAGNE, M.; NDOUR, K.B.; LAHR, J., 1998, Laboratory tests with eight acridicides on Oreochromis niloticus (Pices, Cichlidae). In: Everts, J.W.; Mbaye, D.; Barry, O. and Mullie, W. (Eds.) Environmental side-effects of locust and grasshopper control. Vol. 3, LOCUSTOX Project - GCP/ SEN/041/NET, FAO, Dakar, Senegal, pp. 188-204.

DIAS, M.V; OLIVEIRA, M. R\& SANTELLI, M. G., 2005, Using fluorescence for improvement of the quantitative analysis of micronucleus in cell culture. Mutagenesis, 565: 173-179. DOI:10.1016/j.mrgentox.2004.10.003

GROVER, I. S. \& KAUR, S., 1999, Genotoxicity of wastewater samples from sewage and industrial effluent detected by Allium root anaphase aberration and micronucleus assays. Mutat. Res., 426: 183-188. DOI:10.1016/S0027-5107(99)00065-2

HAINZL, D.; CASIDA, J.E., 1996, Fipronil insecticide: Novel photochemical desulfinylation with retention of neurotoxicity. Proc. Natl. Acad. Sci. USA., 93: 12764-12767.

HURLEY, P.M.; HILL, R.N.; WHITING, R.J., 1998, Mode of carcinogenic action of pesticides inducing thyroid follicular cell tumors in rodents. Environ. Health Perspect., 106(8): 437-445.

RESGALLA. Jr. C; SANTOS, L; SATO, G; EBERHARDT, S. D., 2002, Toxicidade aguda de herbicidas e inseticidas utilizados na cultura do arroz irrigado sobre juvenis de carpa. Pesticidas: $R$. Ecotoxicol. e Meio Ambiente, 12: 59-68.

RIBEIRO, L. R. L; SALVADORI, F. M. D; MARQUES, K. E., 
2003, Mutagênese Ambiental. ULBRA, Canoas, 355p.

RODRIGUES, B. N. \& ALMEIDA, F. S., 1998, Guia de Herbicidas. Londina, 4" ed., 648p.

SANCHES, S. M.; SILVA, C. H.; CAMPOS, S. X. \& VIEIRA, E. M., 2003, Pesticidas e seus respectivos riscos associados à contaminação da água. Pesticidas: R. Ecotoxicol. e Meio Ambiente, 13: 53-58.

SOSBAI, Sociedade Sul Brasileira de Arroz Irrigado, 2003, Arroz irrigado: recomendações técnicas de pesquisa para o sul do Brasil. SOSBAI, Itajaí, SC, 126p.

SUGINARA, T; SAWADA, S; HAKURA, A; HORI, Y; UCHIDA, K; SAGAMI, F. A, 2000, Staining produce for micronucleus test using new methylene blue an acridine orange: specimens that are supravitally stained with possible long-term storage. Mutat. Res., 470: 103-108. DOI:10.1016/S1383-5742(00)00044-2

USEPA, 1996, New pesticide fact sheet. Office of prevention, pesticides and toxic substances. Washington DC, 20460, EPA737-F-96-005.

WHO, World Health Organization, 1999, Classification of pesticides by hazard. International Programme on Chemical Safety. WHO/ IPCS/98.21.

WHO, World Health Organization, 2004, Classification of pesticides by hazard and guide lines to classification. International Programme on Chemical Safety.

WOLF, T. \& LUEPKE, P. N., 1997, Formation of micronuclei in incubated hen's eggs as a measure of genotoxicity. Mutat. Res., 394:163-175. DOI:10.1016/S1383-5718(97)00136-8

WOLF, T; ROLF, N. C.\& LUEPKE, P. N., 2002, Some new methodological aspects of the egg test for micronucleus induction (HET-MN). Mutat. Res., 514:59-76. DOI:10.1016/ S1383-5718(01)00317-5. 